\title{
Treated sewage effluent: Agronomical and economical aspects on bermudagrass production
}

\author{
S.F. Nogueira ${ }^{a}$, B.F.F. Pereira ${ }^{b, *}$, T.M. Gomes ${ }^{c}$, A.M. de Paula ${ }^{d}$, J.A. dos Santos ${ }^{e}$, C.R. Montes ${ }^{f}$ \\ a Embrapa Satellite Monitoring, Avenida Soldado Passarinho, 303, 13070-115 Campinas, SP, Brazil

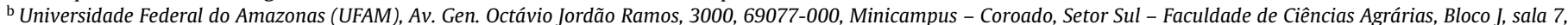 \\ Manaus, AM, Brazil \\ c Universidade de São Paulo (USP), Faculdade de Zootecnia e Engenharia de Alimentos, Av. Duque de Caxias Norte, 225, 13635-900 Pirassununga, SP, Brazil \\ d Universidade Federal do Paraná (UFPR), Campus Palotina, Rua Pioneiro 2153, Jd. Dallas, Palotina, Paranã 85950-000, Brazil \\ e Universdade de São Paulo (USP), Departamento de Economia, Administração e Sociologia, Avenida Centenário, 303, 13416-903 Piracicaba, SP, Brazil \\ ${ }^{\mathrm{f}}$ Universidade de São Paulo (USP), Centro de Energia Nuclear na Agricultura, Avenida Centenário, 303, 13416-903 Piracicaba, SP, Brazil
}

\section{A R T I C L E I N F O}

\section{Article history:}

Received 16 December 2011

Accepted 12 July 2012

Available online 11 August 2012

\section{Keywords:}

Sewage effluent

Reclaimed wastewater

Water reuse

Plant nutrition

Bermudagrass

Nitrogen

\begin{abstract}
A B S T R A C T
This study investigated the effects of irrigation using treated sewage effluent (TSE) combined with nitrogen $(\mathrm{N})$ fertilization on the productivity and quality of bermudagrass, and on its economic feasibility under tropical conditions. The treatments employed were SI - no irrigation and no fertilization; A100 (control) - irrigation with potable water plus $520 \mathrm{~kg} \mathrm{Nha}^{-1}$ year ${ }^{-1}$ provided as $\mathrm{NH}_{4} \mathrm{NO}_{3}$; E0, E33, E66, and E100: irrigation with treated sewage effluent plus $0,172,343$ and $520 \mathrm{~kg} \mathrm{~N} \mathrm{ha}^{-1}$ year $^{-1}$ as $\mathrm{NH}_{4} \mathrm{NO}_{3}$, respectively. Chemical properties of TSE, shoot dry matter production, $\mathrm{N}$ concentration in bermudagrass were determined, and benefit-cost and economic viability analyses were carried out. Tree years of irrigation with TSE had agronomical benefits to bermudagrass such as: (i) saving $33 \%$ in $\mathrm{N}$ fertilizer by

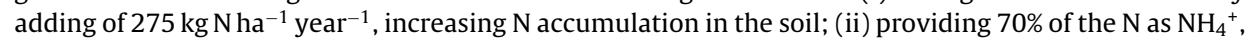
which is the form most quickly assimilated by the plants; (iii) building up dry matter production with $7 \mathrm{Mg} \mathrm{ha}^{-1}$ year $^{-1}$ and (iv) increasing leaf $\mathrm{N}$ concentration in leaf tissue. The main benefit of TSE irrigation occurs in drought seasons with the increase in $\mathrm{N}$ concentration in bermudagrass shoots. Higher $\mathrm{N}$ concentration in leaf tissue elevates the quality and the sales price for the grass harvested, thus optimizing the benefit-cost ratio for the producer. Therefore, TSE irrigation is a viable cost-effective alternative if the $\mathrm{N}$ concentration in the leaf tissue is considered in the sales price.
\end{abstract}

(ㄷ) 2012 Elsevier B.V. All rights reserved.

\section{Introduction}

Previous studies reported the economical, agronomical and environmental benefits of treated sewage effluent (TSE) irrigation (Pereira et al., 2011). Among the nutrients provided by irrigation using TSE the nitrogen $(\mathrm{N})$ is emphasized (Vazquez-Montiel et al., 1996; Oron, 1996; Meli et al., 2002). According to Lemaire and Gastal (1997), N is the most limiting factor for biomass production in agro-ecosystems after water. The $\mathrm{N}$ economy generated by irrigation with TSE is important due to the growing costs of $\mathrm{N}$ fertilization. Between 1960 and 2010 the average U.S. farm price of a ton of urea fertilizer (44-46\% of $\mathrm{N}$ ) increased from US\$ 82 to US\$ 448 (USDA, 2010). Menzel and Broomhall (2006) concluded that TSE costs $50 \%$ of the costs of potable water (PW), thus enabling savings of AU\$ 8000 ha $^{-1}$ year $^{-1}$.

\footnotetext{
* Corresponding author. Tel.: +55 92 88276103; fax: +55 9233054041.

E-mail address: brunoffp2000@yahoo.com.br (B.F.F. Pereira).
}

Among the forage plant crops with potential for TSE irrigation is the bermudagrass. This species responds to $\mathrm{N}$ fertilization, is highly productive under adequate soil humidity conditions, and has high tolerance to salinity (Hill et al., 1993; Alvim et al., 1999; Maas, 1985) and high economic added value. Recent studies have pointed to the influence of: (i) $\mathrm{N}$ sources in different doses; (ii) fertilization seasons and (iii) irrigation with well water, and its effects on the production of bermudagrass. When $\mathrm{N}$ was added as a control-release fertilizer there was an increase of $10 \%$ in the green color of bermudagrass in comparison to bio-solid and to dung pellets (Barton et al., 2006). Bermudagrass responded to irrigation and application of $\mathrm{N}$ to the soil under different doses according to each season of the year (Xiong et al., 2007). Wherley et al. (2009) described that even during the transition months, when there is less growth, bermudagrass assimilated N efficiently. During the late season (September-October), less than $59 \%$ of the $\mathrm{N}$ applied to the soil was recovered (Adeli et al., 2003). Barton et al. (2006) found interaction between the $\mathrm{N}$ fertilizer source, the doses applied and the production of dry matter (DM). These authors state that doses of $200-300 \mathrm{~kg} \mathrm{~N} \mathrm{ha}^{-1}$ per harvest were adequate for the 
production of bermudagrass. Moreover, water-soluble or controlrelease fertilizers doubled the DM production in comparison to organic fertilizers.

Few studies investigated the influence of TSE irrigation as a partial source of $\mathrm{N}$ fertilizer on the production of bermudagrass especially in tropical conditions. In this study, we hypothesized that irrigation using TSE as a partial source of $\mathrm{N}$ associated with $\mathrm{N}$ regular-fertilizer may affect $\mathrm{DM}$ production and $\mathrm{N}$ concentration in the shoots and the economic feasibility. Menzel and Broomhall (2006) identified an increase of $4 \%$ on DM for bermudagrass irrigated with TSE in comparison to irrigation with potable water. These authors reported a $40 \%$ decrease in $\mathrm{N}$ leaf concentration in plants irrigated with TSE between May and August. Mancino and Pepper (1992) detected increase in total $\mathrm{N}$ concentration in the soil during the first year of irrigation with TSE. However, after 2.3 years the $\mathrm{N}$ concentration at the plots irrigated with TSE did not differ from that of the plots irrigated with PW. Irrigation with TSE added $335 \mathrm{~kg} \mathrm{Nha}^{-1}$ year $^{-1}$ to the soil and represented an economy of $32-81 \%$ in $\mathrm{N}$ use in the production of bermudagrass (Fonseca et al., 2007). Fonseca et al. (2007) also detected an increase in protein concentration in bermudagrass irrigated with increasing doses of TSE.

Several studies identified the importance of $\mathrm{N}$ fertilization and irrigation with well water for bermudagrass cultivation. However, few studies investigated the effects of irrigation with TSE on: (i) $\mathrm{N}$ addition to the soil; (ii) dry mass production by the crop; (iii) N leaf concentration; (iv) changes to these variables at different seasons of the year and $(\mathrm{v})$ benefit-cost (BC) ratio of irrigation systems. Although $\mathrm{N}$ economy, other costs, such as those involved in the irrigation system, superior-quality harvest and final quality of the harvested grass must be taken into consideration for the BC ratio. These items may vary with TSE irrigation associated with $\mathrm{N}$ mineral fertilizer. The BC analysis determines which studied investment project (agricultural system) must be selected, based on the greater investment return (Mishan, 1988).

This work aimed at evaluating: (i) the effects of different management practices using irrigation with TSE associated with $\mathrm{N}$ fertilization on the production of bermudagrass and the quality of the hay produced and (ii) the economical feasibility of the use of TSE on the cultivation of bermudagrass.

\section{Materials and methods}

\subsection{Study area}

The field for researches on agricultural reuse was installed at Lins, São Paulo, Brazil (21 $40^{\prime} 43^{\prime \prime}$ S, $49^{\circ} 44^{\prime} 23^{\prime \prime} \mathrm{W}, 437 \mathrm{~m}$ a.s.l.), in an area adjoining the municipal sewage treatment station operated by the sanitation company of the state of São Paulo, SABESP (Companhia de Saneamento Básico do Estado de São Paulo).

The soil in the area is a sandy clay loam, classified as Typic Haplustult (Soil Survey Staff, 1999) according to the physico-chemical characteristics described by Fonseca et al. (2007).

\subsection{Crop and experimental design}

The grass selected for cultivation was Tifton 85 bermudagrass (Cynodon dactylon Pers. $\times$ Cynodon nlemfuensis Vanderyst), due to its tolerance to salinity (Maas, 1985) and its economic added value. The experimental design consisted of completely randomized blocks with six treatments and four replicates. The plots were $10 \mathrm{~m}$ wide, $10 \mathrm{~m}$ long and had a $10-\mathrm{m}$ border. The treatments employed were: (1) SI - no irrigation and no fertilization; (2) A100 (control) - irrigation with PW plus $520 \mathrm{~kg} \mathrm{Nha}^{-1}$ year $^{-1}$ provided as $\mathrm{NH}_{4} \mathrm{NO}_{3}$; (3) E0, (4) E33, (5) E66, and (5) E100: irrigation with TSE plus $0,172,343$ and $520 \mathrm{~kg} \mathrm{~N} \mathrm{ha}^{-1}$ year $^{-1}$ as $\mathrm{NH}_{4} \mathrm{NO}_{3}$ respectively. Fertilizations were divided into six applications along the year, and the $520 \mathrm{~kg} \mathrm{~N} \mathrm{ha}^{-1}$ year $^{-1}$ dose was the standard mineral fertilization amount (Werner et al., 1996).

To simulate harvesting for haymaking, the bermudagrass was removed every two months at a height of $3 \mathrm{~cm}$ from the soil. After felling, all plots except that of the SI treatment received different doses of $\mathrm{N}$ and the same amounts of $\mathrm{K}\left(415 \mathrm{~kg} \mathrm{~K}_{2} \mathrm{O} \mathrm{ha}^{-1}\right.$ year $\left.^{-1}\right)$ applied every two months (Alvim et al., 1999) and simple superphosphate $\left(140 \mathrm{~kg} \mathrm{P}_{2} \mathrm{O}_{5} \mathrm{ha}^{-1}\right.$ year $\left.^{-1}\right)$ applied every six months (Werner et al., 1996).

\subsection{Irrigation system and climate data}

The conventional irrigation system was employed using sprinklers (NAAN model 5024) with 3.0 bar pressure and $0.63 \mathrm{~m}^{3} \mathrm{~h}^{-1}$ flow installed at $90 \mathrm{~cm}$ distance from the soil surface at the center of each plot. Porous cup tensiometers were placed in $0-20,20-40$ and $40-60 \mathrm{~cm}$ soil layers. The tensiometers were read every 2 days, and the irrigation system was activated if the average tensiometer readings were under the critical soil tension for the crop $(-34 \mathrm{kPa})$. Rainfall data were collected using a rain gauge installed locally. Accumulated rainfall was determined for each drought (April-September) and rainfall (October-March) season for the period between 2004 and 2007. The evaluated seasons were named drought-04, rainfall05, drought-05, rainfall-06, drought-06 and rainfall-07, which represented 338, 1000,182, 1026, 151 and $1472 \mathrm{~mm}$ of accumulated rainfall respectively. Rainfall variations during these periods, as well as maximum and minimum temperatures are detailed in Fig. 1.

\subsection{Characteristics of the potable water and the treated sewage}

Treated sewage effluent and PW samples were collected monthly at the irrigation emitters, preserved and prepared according to international standards (Eaton et al., 1995) and the adaptations described below (Table 1 ).

Electrical conductivity (EC) and $\mathrm{pH}$ of the TSE and PW were determined using a $\mathrm{pH} /$ conductivity meter (Model 220, Denver Instrument Inc., Denver, USA). For other analyses, sub-samples of TSE and PW were separated and analyzed in three groups: (i) for dissolved organic carbon (DOC), an aliquot of each sample was filtered through a GF/F glass fiber filter (Whatman ${ }^{\mathrm{TM}}-0.45 \mu \mathrm{m}$ ) and preserved with $\mathrm{HgCl}_{2}$ at $5^{\circ} \mathrm{C}$. Dissolved organic carbon was analyzed by high-temperature catalytic combustion (Shimadzu TOC-500-A, Kyoto, Japan). The GF/F glass fiber filters containing particulate material were dried in a stove at $55-60{ }^{\circ} \mathrm{C}$ for $48 \mathrm{~h}$ and weighed again. Part of the particulate material was stored in tin capsules for posterior total particulate nitrogen (TPN) analysis using an element analyzer (Carlo Erba, model EA 1110). Thus, the $\mathrm{N}$ element composition (\%) was determined as follows: (ii) for the analysis of macro-/micro-nutrients and heavy metals, an aliquot of samples was filtered through an acetate cellulose membrane filter (Millipote ${ }^{\mathrm{TM}}-0.22 \mu \mathrm{m}$ ) and the filtrate was analyzed for the concentrations of $\mathrm{Ca}, \mathrm{Mg}, \mathrm{Na}, \mathrm{B}, \mathrm{Cu}, \mathrm{Fe}, \mathrm{Mn}, \mathrm{Ni}, \mathrm{Zn}, \mathrm{Al}, \mathrm{Cd}$, $\mathrm{Cr}$ by inductively coupled plasma optical emission spectrometry (ICP-OES); and (iii) for the measurement of dissolved inorganic carbon (DIC), $\mathrm{Cl}^{-}, \mathrm{NO}_{3}{ }^{-}$and $\mathrm{NH}_{4}{ }^{+}$, an aliquot of the samples was filtered through an acetate cellulose membrane filter $(0.22 \mu \mathrm{m})$ and preserved with thymol (2-isopropyl-5-methylphenol) at $5{ }^{\circ} \mathrm{C}$ prior to analysis. Dissolved inorganic carbon was determined by hightemperature catalytic combustion. The concentrations of $\mathrm{Cl}^{-}, \mathrm{NO}_{3}{ }^{-}$ and $\mathrm{NH}_{4}{ }^{+}$were analyzed by spectrophotometry (FIAstar model 5000 - FOSS - Höganäs, Sweden). 


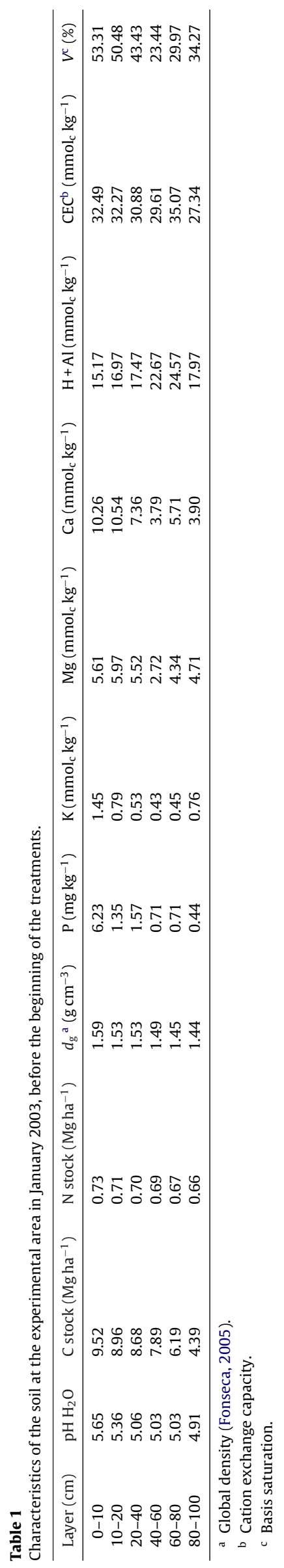

At Table 2, the characteristics of the TSE and PW used for the irrigation of Tifton 85 bermudagrass are compared to values provided by FAO (Ayres and Westcot, 1985), which provides directions on the quality of waters to be used for agricultural irrigation.

\subsection{Dry matter production and $N$ concentration in the shoots}

For the evaluation of DM production, a square of $1.0 \mathrm{~m} \times 1.0 \mathrm{~m}$ was randomly placed at the usable area of the plot. The grass within the quadrant was felled manually. It was then washed with deionized water and dried in a forced-air oven at $60^{\circ} \mathrm{C}$ until constant weight. The DM ( $\mathrm{kg} \mathrm{DM} \mathrm{ha}^{-1}$ year $\left.^{-1}\right)$ production was then estimated for each treatment.

Part of the DM was ground using a "Wiley" mill with a 0.85$\mathrm{mm}$ masher, and was then homogenized. An amount of $1 \mathrm{mg}$ of each sample was taken, stored in a tin capsule and analyzed in an element analyzer (Carlo Erba, model EA 1110) to determine $\mathrm{N}$ composition (\%).

\subsection{Statistical analysis of agronomic data}

The Shapiro-Wilk test $(P>0.05)$ was used to evaluate the normality test of DM and leaf $\mathrm{N}$ data. The comparison among DM averages and $\mathrm{N}$ leaf concentration for each sampling season was made using the Tukey test $(P<0.05)$. Quadratic and linear regression tests were performed to examine the influence of the $\mathrm{N}$ applied to the soil ( $\mathrm{N}$ from fertilizer $+\mathrm{N}$ from TSE) on the DM yield. The best models were chosen based on their statistical significance $(P<0.05)$ and on the coefficient of determination $\left(R^{2}\right)$. The SAS program, version 9.1.2, was used in all statistical analyses.

\subsection{Economical analysis}

The following criteria were considered in this study: (i) fixed period (a period was chosen during which the money must be fully recovered); (ii) reimbursement period (number of years necessary for the recovery of the initial expenses); (iii) average return rate (assumes that all investments, costs and incomes were corrected in terms of the uncertainties); and (iv) average net return rate (the expenses are subtracted from the sum of the benefits before proceeding to the division by number of years). Thus, the analysis was defined by the ratio $(B C)$ between all benefits $(B)$ and the costs $(C)$ associated with the productive process, which resulted in the return on investment rate for each monetary unit invested after subtracting the amount of money over time.

This ratio can be defined by the following equation:

$\mathrm{BC}=\frac{B}{C}=\sum_{t=0}^{n} \frac{B_{t} /(1+r)^{t}}{C_{t} /(1+r)^{t}}$

where $B_{t}$ is the sums of all the costs generated by the productive process; $C_{t}$ the costs associated with the productive process; $n$ the number of periods; $t$ the period of analysis and $r$ is the discount rate considered by the investment.

If $\mathrm{BC}>1$, then the benefits generated will be greater than the investments/costs involved, in which case the project will render itself economically viable (Mishan, 1988).

The benefit-cost analysis was performed in two ways. The first one used an average sales price of US\$ 1.35 for Tifton 85 hay (from 1997 to 2006) (Lima et al., 2006), and the sales prices were calculated as a sensitivity analysis, with $10 \%$ variation. The second analysis considered a sales price according to product quality based 


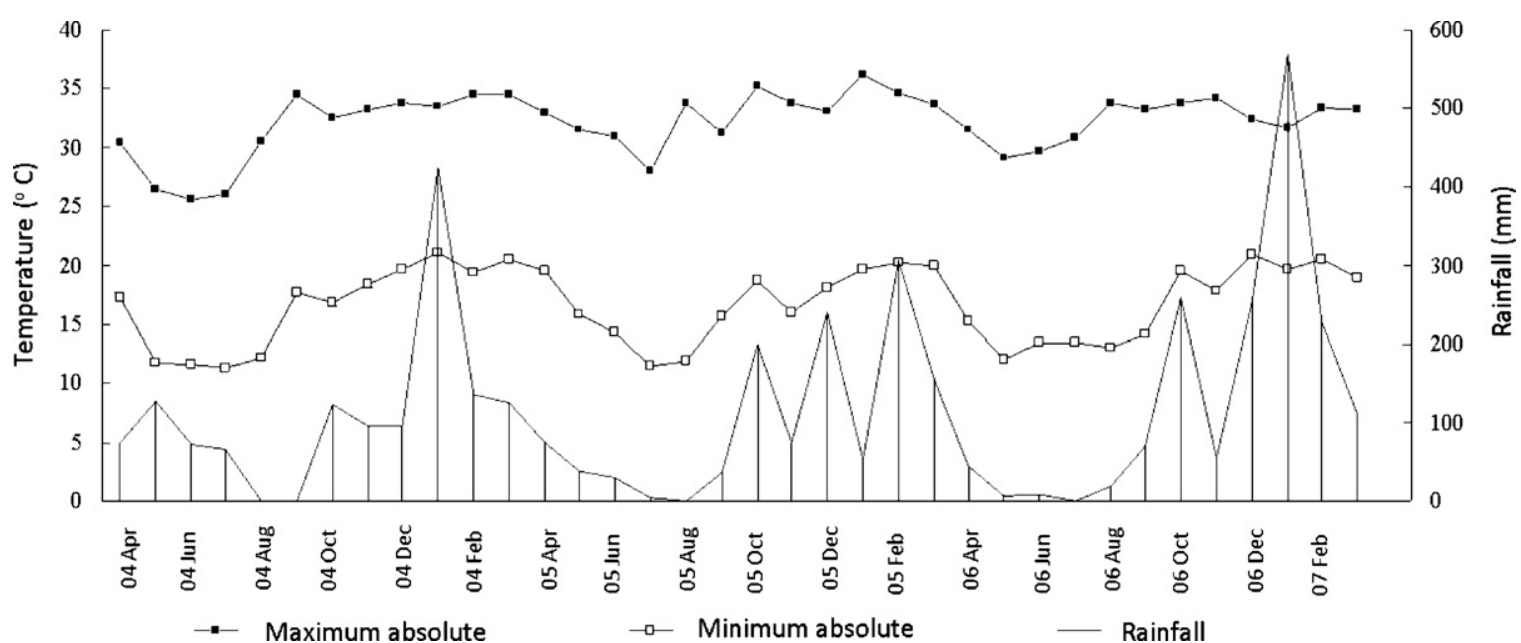

Fig. 1. Average monthly temperatures (absolute maximum and minimum) and monthly rainfall from April 2004 to March 2007.

on $\mathrm{N}$ concentration in the grass. Thus, the greater the $\mathrm{N}$ concentration, the greater the price paid for the grass. This second analysis was important because prior studies (Itavo et al., 2002; Lima et al., 2006) have shown a close relationship between $N$ concentration in the feed and protein gains for the animals.

To complement the aforementioned analysis, we chose to work with investment analysis, that is, with net present value (NPV) and internal rate of return (IRR). The NPV is a method for economic evaluation which conveys future payments to the present value and deducts an interest rate minus the initial investment value. The IRR, frequently used for the evaluation of investments, is a method defined as the deduction rate that makes the NPV equal zero (Lapponi, 2007). Thus, the mathematical formula for the calculation of the NVP is:

$\mathrm{NPV}=\sum_{t=1}^{n} \frac{C F_{t}}{(1+i)^{j}}-C F_{0}$

where $C F_{t}$ is the cash flow during the " $t$ " period; $C F_{0}$ the cash flow during the " 0 " period; $i$ the interest rate; $t$ the analyzed time period and $n$ is the number of periods.

Thus, the result obtained for the NVP can be interpreted as:

- If $\operatorname{NVP}(i)>0$, the project should be accepted;

Table 2

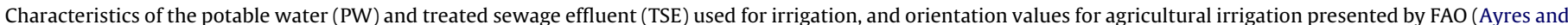
Westcot, 1985).

\begin{tabular}{|c|c|c|c|c|c|c|}
\hline \multirow[t]{2}{*}{ Characteristics } & \multirow[t]{2}{*}{ Unit } & \multirow[t]{2}{*}{ PW } & \multirow[t]{2}{*}{ TSE } & \multicolumn{3}{|c|}{ Degrees of restriction to use $\mathrm{e}^{\mathrm{a}}$} \\
\hline & & & & Low & Low to moderate & Severe \\
\hline TSS $^{\mathrm{b}}$ & $\mathrm{mg} \mathrm{L}^{-1}$ & - & $127.8 \pm 20.4$ & $<50$ & $50-100$ & $>100$ \\
\hline $\begin{array}{l}\text { Salinity } \\
\text { EC }^{\mathrm{c}} \\
\text { TDS }^{\mathrm{d}}\end{array}$ & $\begin{array}{l}\mathrm{dS} \mathrm{m^{-1 }} \\
\mathrm{mg} \mathrm{L}^{-1}\end{array}$ & $\begin{array}{l}0.43 \pm 0.1 \\
429 \pm 67\end{array}$ & $\begin{array}{l}0.85 \pm 0.1 \\
691 \pm 70\end{array}$ & $\begin{array}{l}<0.7 \\
<450\end{array}$ & $\begin{array}{l}0.7-3.0 \\
450-2000\end{array}$ & $\begin{array}{l}>3.0 \\
>2000\end{array}$ \\
\hline $\begin{array}{l}\text { Infiltration } \\
\text { SAR }^{\mathrm{e}} \text { from } 6 \text { to } 12 \\
\text { SAR from } 20 \text { to } 40\end{array}$ & $\left(\mathrm{mmol} \mathrm{L}^{-1}\right)^{0.5}$ & $32.2 \pm 10.1$ & $11.9 \pm 2.9$ & $\begin{array}{l}C E>1.9 \\
C E>5.0\end{array}$ & $\begin{array}{l}1.9 \geq C E \geq 0.5 \\
5.0 \geq C E \geq 2.9\end{array}$ & $\begin{array}{l}C E<0.5 \\
C E<2.9\end{array}$ \\
\hline $\begin{array}{l}\text { Toxicity } \\
\mathrm{Na}^{+} \\
\mathrm{Cl}^{-} \\
\mathrm{B}^{\mathrm{e}} \\
\mathrm{HCO}_{3}^{-} \\
\mathrm{N}^{-} \mathrm{NO}_{3}{ }^{-} \\
\mathrm{pH}\end{array}$ & $\begin{array}{l}\mathrm{mg} \mathrm{L}^{-1} \\
\mathrm{mg} \mathrm{L}^{-1} \\
\mathrm{mg} \mathrm{L}^{-1} \\
\mathrm{mg} \mathrm{L}^{-1} \\
\mathrm{mg} \mathrm{L}^{-1}\end{array}$ & $\begin{array}{l}88.9 \pm 33.5 \\
5.9 \pm 1.08 \\
0.15 \pm 0.04 \\
231.3 \pm 22.5 \\
0.42 \pm 0.5 \\
9.5 \pm 0.6\end{array}$ & $\begin{array}{l}131.7 \pm 6.6 \\
63.4 \pm 7.9 \\
0.17 \pm 0.08 \\
449.0 \pm 79.1 \\
0.80 \pm 0.6 \\
7.5 \pm 0.5\end{array}$ & $\begin{array}{l}<69 \\
<106 \\
<0.7 \\
<92 \\
<5\end{array}$ & $\begin{array}{l}>69 \\
>106 \\
0.7-3.0 \\
92-519 \\
5-30 \\
\text { Normal interval 6.5-8.0 }\end{array}$ & $\begin{array}{l}>3.0 \\
>519 \\
>30\end{array}$ \\
\hline $\begin{array}{l}\text { Other elements } \\
\mathrm{Al} \\
\mathrm{Cd} \\
\mathrm{Cr} \\
\mathrm{Cu} \\
\mathrm{F} \\
\mathrm{Fe} \\
\mathrm{Mn} \\
\mathrm{Ni} \\
\mathrm{Zn}\end{array}$ & $\begin{array}{l}\mathrm{mg} \mathrm{L}^{-1} \\
\mathrm{mg} \mathrm{L}^{-1} \\
\mathrm{mg} \mathrm{L}^{-1} \\
\mathrm{mg} \mathrm{L}^{-1} \\
\mathrm{mg} \mathrm{L}^{-1} \\
\mathrm{mg} \mathrm{L}^{-1} \\
\mathrm{mg} \mathrm{L}^{-1} \\
\mathrm{mg} \mathrm{L}^{-1} \\
\mathrm{mg} \mathrm{L}^{-1}\end{array}$ & $\begin{array}{l}0.04 \pm 0.02 \\
\mathrm{n} / \mathrm{a}^{\mathrm{f}} \\
\mathrm{n} / \mathrm{a} \\
0.001 \pm 0.001 \\
0.70 \pm 0.14 \\
\mathrm{n} / \mathrm{a} \\
0.002 \pm 0.002 \\
\mathrm{n} / \mathrm{a} \\
\mathrm{n} / \mathrm{a}\end{array}$ & $\begin{array}{l}0.03 \pm 0.02 \\
\text { n/a } \\
\text { n/a } \\
0.002 \pm 0.001 \\
0.48 \pm 0.32 \\
0.08 \pm 0.06 \\
0.015 \pm 0.006 \\
\text { n/a } \\
0.02\end{array}$ & & $\begin{array}{c}\text { Range values } \\
5.0 \\
0.01 \\
0.1 \\
0.2 \\
1.0 \\
5.0 \\
0.2 \\
0.2 \\
2.0\end{array}$ & \\
\hline
\end{tabular}

a Ayres and Westcot (1985)

b Total suspended solids.

c Electrical conductivity.

d Total dissolved solids (Gloaguen et al., 2007).

e Sodium adsorption ratio in the intervals of the SAR values determined for water and for treated sewage; Fonseca et al., 2007.

f Concentration below the detection limit. 


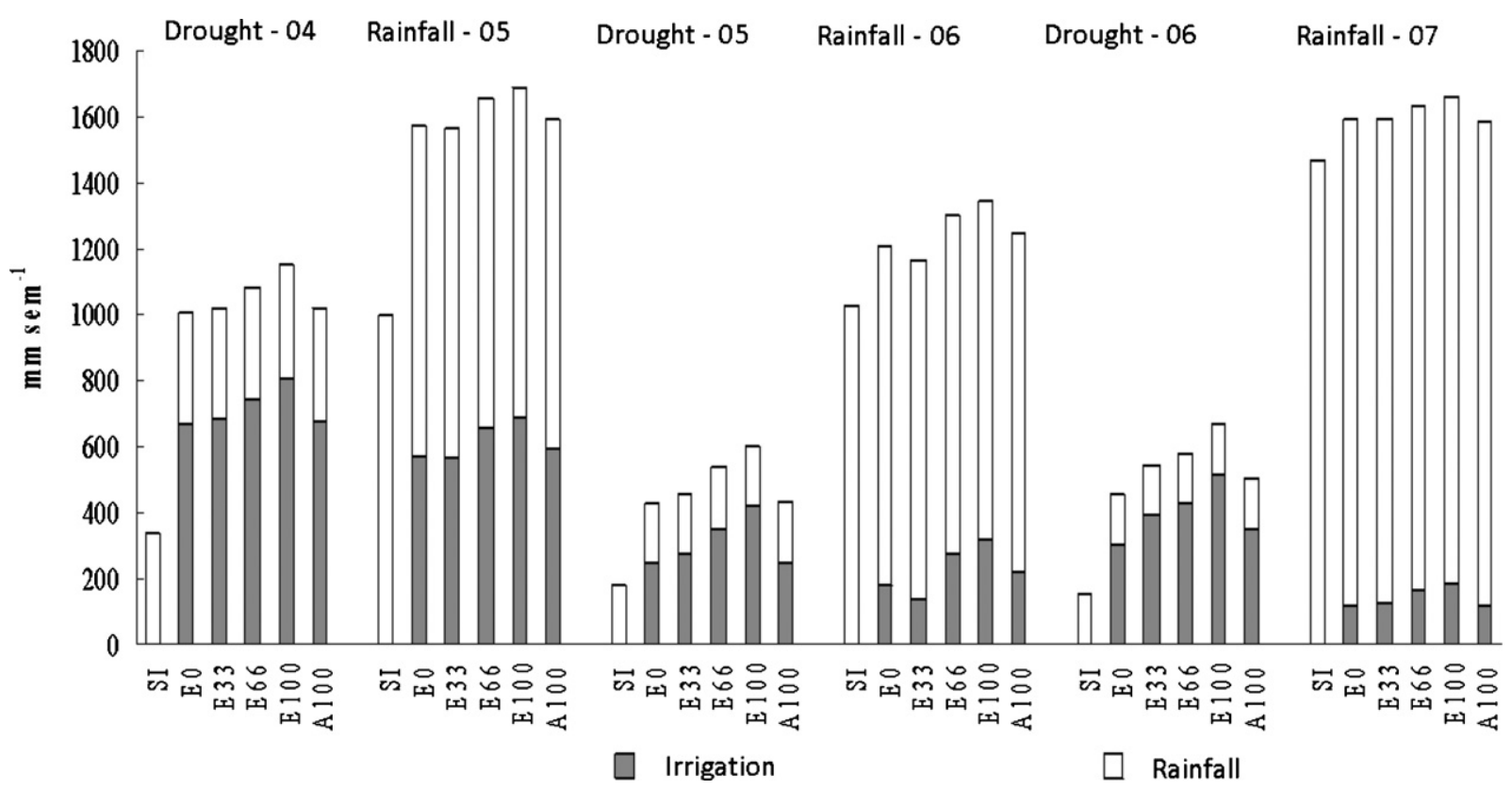

Fig. 2. Semestrial $\left(\mathrm{sem}^{-1}\right)$ irrigation rates and rainfall in treatments at the Tifton 85 bermudagrass experimental area.

- If $\mathrm{NVP}(i)<0$, the project should be declined;

- If $\operatorname{NVP}(i)=0$, the project is within the required rate, but adds no value to the company.

The mathematical formula for calculating IRR is:

$$
\sum_{t=1}^{n} \frac{C F_{t}}{(1+\mathrm{IRR})^{t}}-C F_{0}=0
$$

where $C F_{0}$ is the cash flow during the "O" period.

\subsection{Database for economic analysis}

In this research the benefit generated by irrigation using treated sewage in Tifton 85 crops was evaluated. A BC ratio for the treatments studied was proposed for a study period $(t)$ from April 2004 to March 2007. The criterion used for analysis was the value of the commercial hay product, with initial investment and annual costs of crop production.

For the calculation of the initial costs for PW and TSE irrigation, we considered: collector pipeline, gravity pressure pump pumping the TSE from the exit of the stabilization lagoons to the pumping headline at the experimental area $(100 \mathrm{~mm}$ diameter and $115 \mathrm{~m}$ distance); for the PW irrigation system a $5000 \mathrm{~L}$ reservoir was included. These costs were annually prorated by linear depreciation (10 years), by capital recovery factor ( $5.5 \%$ per year, according to the real interest rate of the Brazilian Development Bank, BNDES), and by the uniform series of payments (Frizzone and Silveira, 2000).

The costs were composed of planting, supplies, irrigation and harvesting costs. The planting costs comprised soil preparation (laborer hourly rate), dolomitic lime (kg), lime application (laborer $\mathrm{day}^{-1}$ ), plantlet $(\mathrm{Mg})$, labor for plantlet planting (laborer day ${ }^{-1}$ ). For crop maintenance supplies, different $\mathrm{NH}_{4} \mathrm{NO}_{3}$ and $\mathrm{K}_{2} \mathrm{O}$ measures ( $\mathrm{kg}$ ) were considered for each treatment.

The cost of the irrigation system was determined for irrigation with PW and TSE. For the variable costs we considered electricity, management labor and irrigation operation. The price of the PW irrigation system was added as a variable cost in terms of each irrigation rate used. The value used for the calculations were based on the current charges for the Paraíba do Sul and PiracicabaCapivari-Jundiaí river basins according to the Brazilian National
Waters Agency (ANA) resolution number 308, from August 6, 2007.

For the harvest, a cost of $40 \%$ of the gross income generated by hay sales was established. ${ }^{1}$

\section{Results}

\subsection{Characteristics of treated sewage and of potable water}

The total suspended solids (TSSs) values for treated sewage effluent (Table 2) were considered severely restrictive for use in agricultural irrigation. Potable water showed "low" degree of restriction for electrical conductivity (EC) and total dissolved solids (TDS). Treated sewage effluent showed "low to moderate" degree of restriction for these variables. Potable water and TSE also showed "high" and "low to moderate" risks for sodification, respectively. The smaller value of sodium adsorption ratio (SAR) showed by TSE in comparison to $\mathrm{PW}$ is explained by the greater concentrations of $\mathrm{Ca}$ and $\mathrm{Mg}$ in the TSE. In terms of $\mathrm{Na}$ and $\mathrm{HCO}_{3}$ concentrations, the degree of restriction was "low to moderate" for both PW and TSE. Chloride, $\mathrm{B}$ and $\mathrm{N}_{-} \mathrm{NO}_{3}{ }^{-}$concentrations classified as adequate for agricultural use for both types of irrigation water. The $\mathrm{pH}$ of potable water was above the normal range, and other elements ( $\mathrm{Al}, \mathrm{Cd}, \mathrm{Cr}$, $\mathrm{Cu}, \mathrm{F}, \mathrm{Fe}, \mathrm{Mn}, \mathrm{Ni}$, and $\mathrm{Zn}$ ) were found in concentrations lower than the limiting values.

\subsection{Nitrogen supply to the soil}

The greatest volumes of TSE irrigation were observed in the drought seasons (Fig. 2). However, the 2005 rainfall station showed lower indices of rainfall, with rain occurrences irregularly distributed (Fig. 1), which demanded greater irrigation volumes. The E66 treatment received, through the TSE, an average of 160 and $115 \mathrm{kgha}^{-1}$ per semester of $\mathrm{N}\left(\mathrm{TPN}+\mathrm{NH}_{4}{ }^{+}-\right.$ $\mathrm{N}+\mathrm{NO}_{3}{ }^{-}-\mathrm{N}$ ) in the drought and rainy seasons respectively, in a total of $275 \mathrm{~kg} \mathrm{Nha}^{-1}$ year $^{-1}$ (Fig. 3). This treatment also

\footnotetext{
1 The harvest costs were provided by Prof. Ph.D. Luiz Gustavo Nussio nussio@esalq.usp.br.
} 


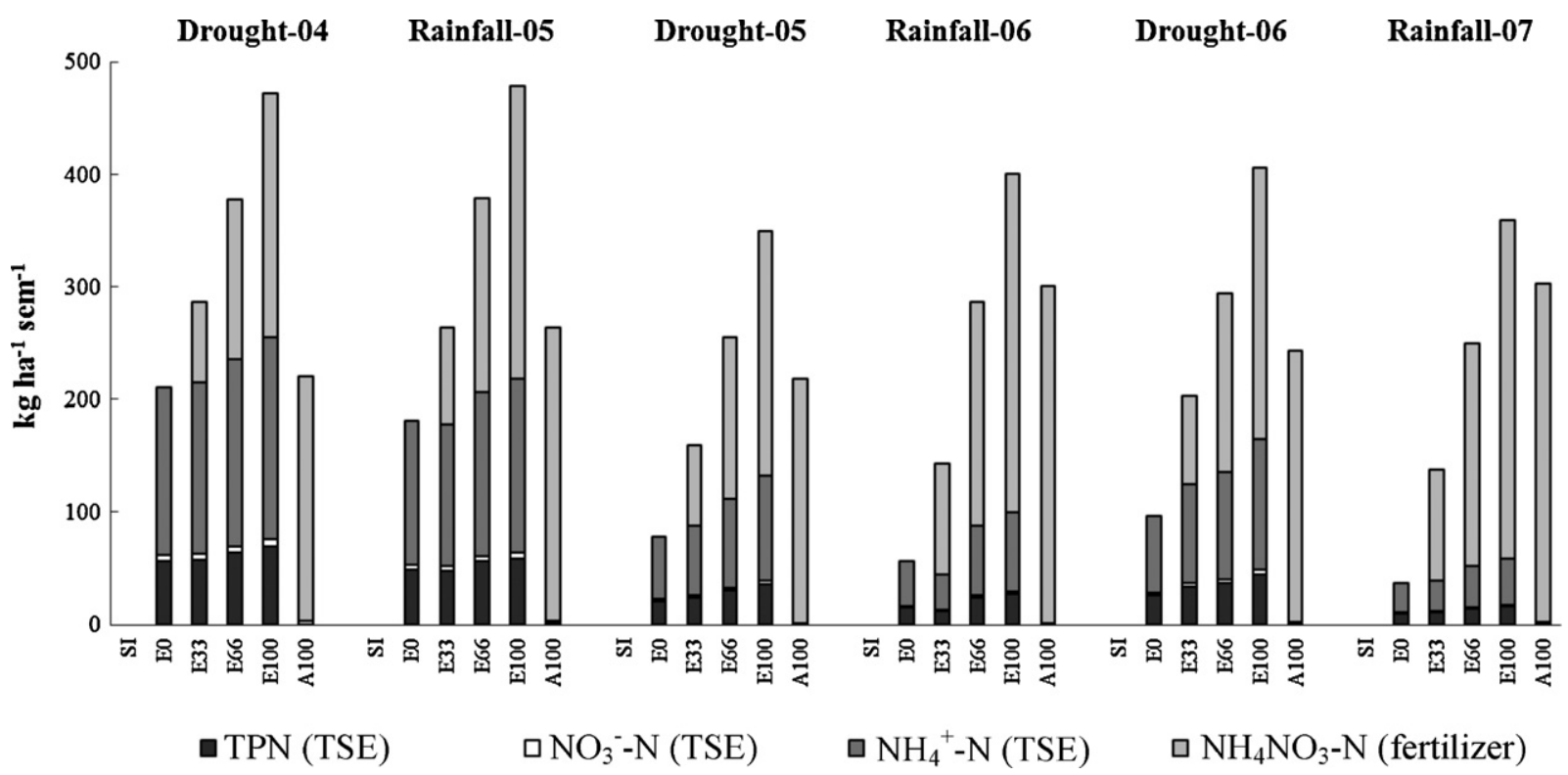

Fig. 3. Nitrogen (TPN, $\mathrm{NH}_{4}{ }^{+}-\mathrm{N}$ and $\mathrm{NO}_{3}{ }^{-}-\mathrm{N}$ ) supplied to the soil by means of irrigation with TSE and water, and mineral fertilizer.

received $337 \mathrm{~kg} \mathrm{Nha}^{-1}$ year $^{-1}$ of mineral fertilizer, in total 612 $(275+337) \mathrm{kg} \mathrm{Nha}^{-1}$ year $^{-1}$. In general, except for the two first seasons, treatment E66 was the most similar to the control treatment - A100 (520 kg Nha-1 year $\left.^{-1}\right)$ - in terms of $\mathrm{N}$ supply to the soil. Treatment E100 supplied a total of $829 \mathrm{~kg} \mathrm{~N} \mathrm{ha}^{-1} \mathrm{year}^{-1}$, $309 \mathrm{~kg} \mathrm{Nha}^{-1}$ year $^{-1}$ through the TSE plus $520 \mathrm{~kg} \mathrm{Nha}^{-1}$ year $^{-1}$ through mineral fertilization, a much greater amount of $\mathrm{N}$ compared to treatment A100. Treatments E0 and E33 almost always received smaller $\mathrm{N}$ amounts than $\mathrm{A} 100$.

\subsection{Dry matter production}

Irrigation with TSE influenced DM production during all the seasons studied (Fig. 4). E66 and E100 were the only treatments that performed better or that did not differ $(P>0.05)$ from the control treatment (A100)(Fig. 4). Treatments E0 and SI showed the smallest DM production averages for all seasons studied (Fig. 4).

\subsection{Nitrogen supply to the soil and dry matter production}

There was a quadratic correlation $(P<0.01)$ between the concentration of $\mathrm{N}$ applied to the soil $\left(\mathrm{N}_{\text {fertilizer }}+\mathrm{N}_{\text {TSE }}\right)$ and DM production, with $R^{2}$ varying between 0.92 and 0.97 (Fig. 5). The points of maximum DM production were obtained for each season studied by differentiating the correlation equations $(\mathrm{dDM} / \mathrm{dN}=0)$. In drought and rainfall seasons, the maximum average DM production, 18 and $26 \mathrm{Mg} \mathrm{ha}^{-1}$ per semester, was estimated by applying 428 and $289 \mathrm{~kg} \mathrm{Nha}^{-1}$ per semester respectively (Fig. 5).

\subsection{Nitrogen in the shoots}

Generally, the greatest leaf $\mathrm{N}$ concentrations were obtained in the drought seasons for all treatments (Fig. 6). The treatments had no influence on leaf $\mathrm{N}$ concentration for rainfall seasons and for the first drought season. However, for two of the three drought seasons

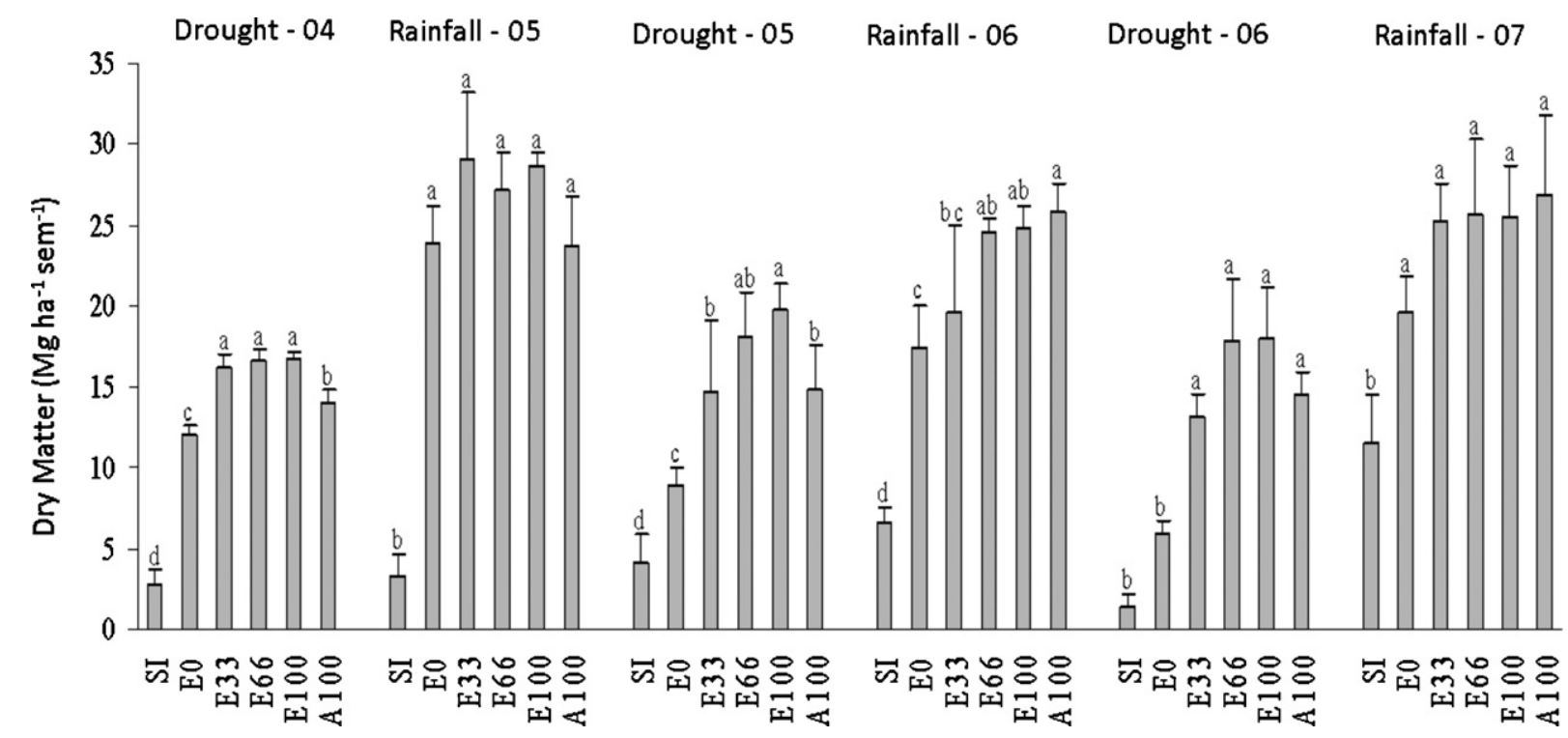

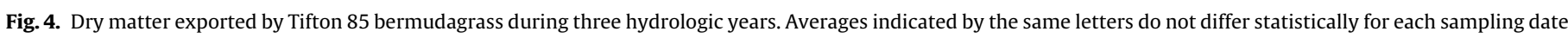
$(t)$ (Tukey, $P<0.05$ ). 


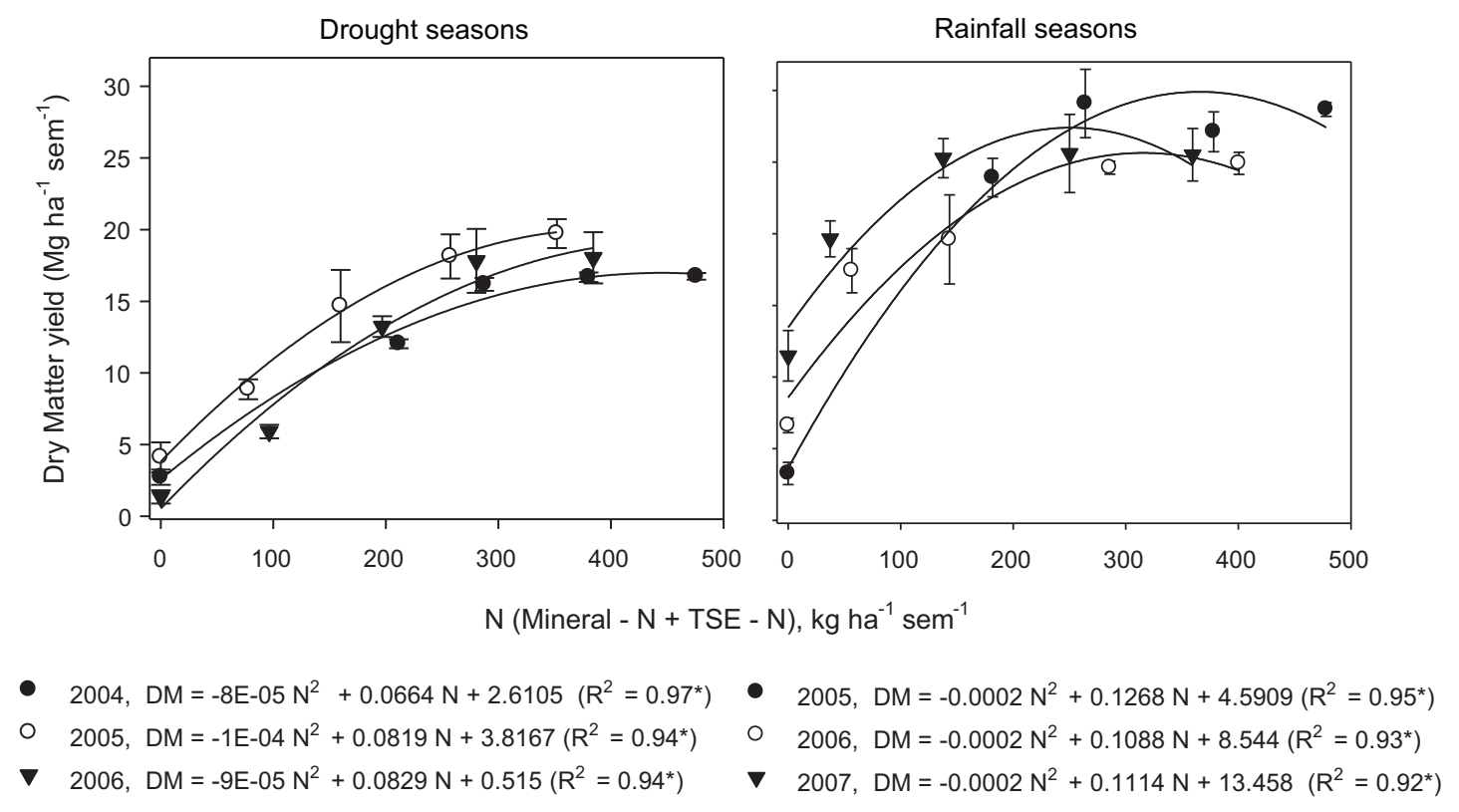

Fig. 5. Influence of $N$ doses from mineral fertilizer and from treated sewage effluent (TSE) in (a) the drought $(04-06)$ and $(b)$ the rainy $(05-07)$ seasons $\left({ }^{*} P<0.01\right)$.

studied, treatments E66 $(2.4 \% \mathrm{~N})$ and E100 $(2.7 \%)$ were equal or superior to treatment $\mathrm{A} 100(2.2 \% \mathrm{~N})$ in terms of leaf $\mathrm{N}$ concentration.

\section{Discussion}

\subsection{Nitrogen supply to the soil}

Treatment E66 supplied $612 \mathrm{~kg} \mathrm{Nha}^{-1}$ year $^{-1}$, part from TSE (45\%) and part from the mineral fertilizer (55\%), and approached mostly A100 (520 kg N ha ${ }^{-1}$ year $^{-1}$ ) in terms of $\mathrm{N}$ supply to the soil (Fig. 3), thus confirming an economy of $33 \%$ of $\mathrm{N}$ due to the supply of TPN, $\mathrm{NO}_{3}{ }^{-}$and $\mathrm{NH}_{4}{ }^{+}$from the TSE. This result is similar to the previously found result of Fonseca et al. (2007) who reported an annual $\mathrm{N}$ supply to the soil by irrigation with TSE of $335 \mathrm{~kg} \mathrm{~N} \mathrm{ha}^{-1}$ year $^{-1}$.

Although treatment E100 supplied the greatest amounts of $\mathrm{N}$ to the soil, $829 \mathrm{~kg} \mathrm{Nha}^{-1}$ year $^{-1}$ (Fig. 3), no considerable increase in DM (Fig. 4) and leaf $\mathrm{N}$ concentration were generally observed in the plants under this treatment (Fig. 6). Therefore, there may be an

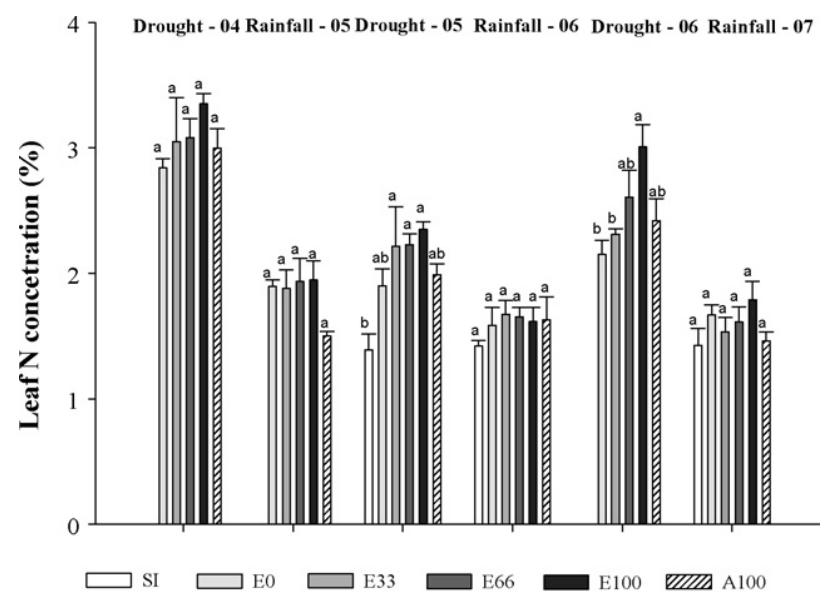

Fig. 6. Leaf nitrogen concentration in Tifton 85 bermudagrass during three hydrological years. Averages indicated by the same letter do not differ statistically (Tukey, $P<0.05$ ) for each sampling date. increasing tendency in $\mathrm{N}$ loss by soil leaching, since there was no increase in $\mathrm{N}$ recovery by the plant.

Mineral $\mathrm{N}$ fertilization applied as $\mathrm{NH}_{4} \mathrm{NO}_{3}$ source supplies $77 \%$ of $\mathrm{N}$ as $\mathrm{NO}_{3}{ }^{-}$and $22 \%$ as $\mathrm{NH}_{4}{ }^{+}$, thus a much greater amount of $\mathrm{NO}_{3}{ }^{-}$is supplied per $\mathrm{kg}$ of $\mathrm{NH}_{4} \mathrm{NO}_{3}$. On the other hand, TSE supplied the major amount of the $\mathrm{N}^{2} \mathrm{NH}_{4}{ }^{+}$(Fig. 3), which is an advantage for plant nutrition. In a total of $276 \mathrm{~kg} \mathrm{~N} \mathrm{ha}^{-1}$ year $^{-1}, 70 \%$ of $\mathrm{N}$ was supplied as $\mathrm{NH}_{4}{ }^{+}, 3 \%$ as $\mathrm{NO}_{3}{ }^{-}$, and $27 \%$ as TPN.

The TSE treatments optimize plant nutrition due to the predominance of $\mathrm{N}_{\text {as }} \mathrm{NH}_{4}{ }^{+}$, which is known to be the preferred $\mathrm{N}$ form in the absorption process and which is also promptly assimilated during the synthesis of amino acids. It has been confirmed that the greatest leaf and thatch production in bermudagrass was obtained with the supply of $\mathrm{N}-\mathrm{NH}_{4}{ }^{+}$instead of $\mathrm{N}-\mathrm{NO}_{3}{ }^{-}$(Bergareche and Simon, 1989). The $\mathrm{N}-\mathrm{NH}_{4}{ }^{+}$absorbed by the plant is quickly assimilated as amino acids. On the other hand, $\mathrm{N}_{-} \mathrm{NO}_{3}{ }^{-}$is absorbed against chemical/electrical gradients, and thus requires more energy, as $\mathrm{NAD}(\mathrm{P}) \mathrm{H}$ (the reducing agent of $\mathrm{NO}_{3}{ }^{-}$) for its assimilation (Bloom, 1997).

Therefore the TSE irrigation of bermudagrass provide an economy of 33\% of $\mathrm{N}$ fertilizer, besides providing $70 \%$ of the $\mathrm{N}$ as $\mathrm{NH}_{4}{ }^{+}$, which is the form most quickly assimilated by the plants.

\subsection{Dry matter production}

Dry mass produced by plots E66 and E100 did not differ $(P>0.05)$ from one another (Fig. 4), but were greater than or similar to those produced in treatments A100, E0, E33 and SI. Dry matter production averages for treatments E66, E100 and A100 in all seasons were of 46,44 and $39 \mathrm{Mg} \mathrm{ha}^{-1}$ year $^{-1}$. Aiming at the greatest DM production and greatest mineral fertilizer economy, treatment E66 is the most recommended one, since it was similar to A100 and performed better than the other treatments. In tropical conditions a previous study report $39 \mathrm{Mg} \mathrm{DM} \mathrm{ha}^{-1}$ year $^{-1}$ for the plots irrigated with TSE (Fonseca et al., 2007) similar with our results.

Correlations between the $\mathrm{N}$ applied to the soil $\mathrm{x}$ DM production have shown a greater need for $\mathrm{N}$ in drought than during rainfall seasons in order to obtain maximum productivities (Fig. 5). In Oklahoma, bermudagrass responded differently to $\mathrm{N}$ according to each period of the year (Xiong et al., 2007). According to Wherley et al. (2009), substantial amounts of TSE can be applied to the soil and the $\mathrm{N}$ will be efficiently assimilated even during transition months, 
Table 3

Benefit-cost ratio for fixed prices and prices varying according to Tifton 85 hay quality and economic viability analysis for each treatment.

\begin{tabular}{|c|c|c|c|c|c|c|c|c|}
\hline Treatment & \multicolumn{2}{|c|}{$\begin{array}{l}\text { Period from } 2004 \text { to } 2007 \\
\text { (US\$ } 1.35 / \mathrm{kg} \text { ) }\end{array}$} & \multicolumn{2}{|c|}{$\begin{array}{l}\text { Period from } 2004 \text { to } 2007 \\
\text { with N price variation }\end{array}$} & \multicolumn{2}{|c|}{$\begin{array}{l}\text { Period from } 2004 \text { to } 2007 \\
\text { (US\$ } 1.21 / \mathrm{kg} \text { ) }\end{array}$} & \multicolumn{2}{|c|}{$\begin{array}{l}\text { Period from } 2004 \text { to } 2007 \\
\text { (US\$ } 1.48 / \mathrm{kg} \text { ) }\end{array}$} \\
\hline \multicolumn{9}{|c|}{ Cost-benefit $\left[(C-B) h a^{-1}\right]$} \\
\hline SI & 1.40 & & 1.53 & & 1.25 & & 1.48 & \\
\hline W100 & 1.27 & & 1.63 & & 1.12 & & 1.33 & \\
\hline E0 & 1.19 & & 1.50 & & 1.05 & & 1.25 & \\
\hline E33 & 1.24 & & 1.66 & & 1.10 & & 1.31 & \\
\hline E66 & 1.24 & & 1.67 & & 1.10 & & 1.30 & \\
\hline E100 & 1.21 & & 1.66 & & 1.07 & & 1.27 & \\
\hline \multirow[t]{2}{*}{ Treatment } & \multicolumn{2}{|c|}{$\begin{array}{l}\text { Period from } 2004 \text { to } 2007 \\
\text { (US\$ } 1.35 / \mathrm{kg} \text { ) }\end{array}$} & \multicolumn{2}{|c|}{$\begin{array}{l}\text { Period from } 2004 \text { to } 2007 \\
\text { with N price variation }\end{array}$} & \multicolumn{2}{|c|}{$\begin{array}{l}\text { Period from } 2004 \text { to } 2007 \\
\text { (US\$ } 1.21 / \mathrm{kg} \text { ) }\end{array}$} & \multicolumn{2}{|c|}{$\begin{array}{l}\text { Period from } 2004 \text { to } 2007 \\
\text { (US\$ } 1.48 / \mathrm{kg} \text { ) }\end{array}$} \\
\hline & NVP (US\$) & $\operatorname{IRR}(\%)$ & NVP (US\$) & $\operatorname{IRR}(\%)$ & NVP (US\$) & $\operatorname{IRR}(\%)$ & NVP (US\$) & $\operatorname{IRR}(\%)$ \\
\hline \multicolumn{9}{|c|}{ Economic viability analysis (ha) } \\
\hline SI & 384.63 & 24 & 597.28 & 33 & 149.71 & 13 & 619.54 & 35 \\
\hline W100 & 506.54 & 12 & 3330.74 & 50 & -463.72 & - & 1476.80 & 25 \\
\hline E0 & -221.76 & - & 1671.21 & 33 & -942.15 & - & 498.63 & 14 \\
\hline E33 & 497.71 & 13 & 3725.27 & 62 & -468.15 & - & 1463.56 & 27 \\
\hline E66 & 639.68 & 15 & 4345.19 & 66 & -417.69 & - & 1697.06 & 30 \\
\hline E100 & 471.01 & 12 & 4482.56 & 67 & -615.62 & - & 1557.65 & 28 \\
\hline
\end{tabular}

NVP, net present value. IRR, internal rate return.

when there is lower growth of the grass. Treated sewage effluent is important during drought seasons not only as an alternative source of water, but also as a complementary source of $\mathrm{N}$, which induces an increase in DM production.

In our study, during drought and rainfall seasons the maximum average productions of 18 and $26 \mathrm{Mg} \mathrm{DM} \mathrm{ha}^{-1}$ per semester were estimated by applying 428 and $289 \mathrm{~kg} \mathrm{Nha}^{-1}$ per semester (Fig. 5). These values are similar to the maximum bermudagrass production of $20 \mathrm{MgDM} \mathrm{ha}^{-1}$ obtained by Osborne et al. (1999). In a single annual harvest, Lima et al. (2010) obtained maximum DM production by applying $355 \mathrm{~kg} \mathrm{Nha}^{-1}$, value similar to the average maximum values estimated in our study of 358 $(428 / 2+289 / 2) \mathrm{kg} \mathrm{Nha}^{-1}$. The lowest DM productions in drought seasons (autumn/winter) in comparison to rainfall seasons were expected and are related to the low temperatures (Fig. 1). It is known that temperatures $<18^{\circ} \mathrm{C}$ interrupts shoot growth and the development of new rhizomes in bermudagrass (Bergareche and Simon, 1989).

Therefore, the supply of $\mathrm{N}$ to the soil by means of TSE is important for productivity increase during both rainfall and drought seasons.

\subsection{Shoot nitrogen concentration}

Treated sewage effluent (E33, E66 and E100) had no influence on leaf $\mathrm{N}$ concentration during rainy seasons. This result was expected and is related to the lower volumes of TSE irrigation during rainfall seasons, and consequently to the lower supply of $\mathrm{N}$ to the soil. However, for drought seasons 05 and 06, treatments E66 and E100 were superior or similar to treatment A100 in terms of leaf $\mathrm{N}$ concentration, which enhanced the nutritional quality of the harvested grass. This increase in leaf $\mathrm{N}$ is a result of the $\mathrm{N}$ supplied to the soil by means of the TSE. Therefore, the benefit of irrigation with TSE in the quality of the harvested grass in terms of $\mathrm{N}$ concentration occurs mainly in drought seasons.

Irrigation with TSE supplied significant amounts of $\mathrm{NH}_{4}{ }^{+}-\mathrm{N}$ to the plants (Fig. 3). When the $\mathrm{N}$ is supplied to the plants in the form of $\mathrm{NH}_{4}{ }^{+}$instead of $\mathrm{NO}_{3}{ }^{-}$, there is a significant increase in DM production as well as in $\mathrm{N}$ accumulation in the shoots (Bergareche and Simon, 1989). As discussed, treatments E66 and E100 supplied greater amounts of $\mathrm{N}$ to the soil in comparison to treatment $\mathrm{A} 100$
(Fig. 3). This explains the greater leaf $\mathrm{N}$ concentration for these treatments in drought seasons 05 and 06.

In terms of $\mathrm{N}$ supply to the soil, DM production and $\mathrm{N}$ concentration in the plants, treatment E66 was superior or similar to A100. In terms of fertilizer economy, E66 is the most recommended treatment. Treatment E33 is not recommended, since it showed DM productions lower than those of treatments E66 and A100 in two seasons (drought-05 and rainfall-06) (Fig. 4) and, in one season (drought-06) the plants showed lower leaf $\mathrm{N}$ concentrations.

\subsection{Economic analysis}

The first $\mathrm{BC}$ analysis considered the grass sold as a homogeneous product and the payment made using a single market price: US\$ 1.35 for the period 2004-2007. Table 3 shows that the return provided by treatment SI was similar to those of treatments irrigated with TSE supplemented by mineral fertilization (E33, E66, E100). This means that even if the producer did not manage his crop, he would obtain a satisfactory return on investment.

The second BC ratio, NVP, IRR analysis type considered the payment for the quality of the hay based on the levels of $\mathrm{N}$ in the plant. The results were quite distinct from those of the first analysis (Table 3). Only E0 showed disadvantage in comparison to SI, which means that all treatments obtained returns on investment substantially greater than SI. The quality of the produced Tifton 85 grass can be inferred from the greater benefits generated by irrigation. The best benefit-cost ratio was that of E66 (1.67), which also presented the greatest IRR (Table 3). This means that the benefits generated by treatment E66 were $67 \%$ greater than the investments and costs involved in that activity, and had a 66\% IRR. Therefore, irrigation with TSE supplements $33 \%$ of the mineral fertilization, leads to an increase in the BC ratio and in IRR for the $C$. dactylon crop as long as the grass quality ( $\mathrm{N}$ concentration in shoots) is taken into consideration.

One last analysis considered the hay price variation as $10 \%$, and SI was the only treatment which presented satisfactory values for $\mathrm{BC}$ ratio, NVP and IRR, i.e. with the hay prices reduced in $10 \%$ a satisfactory return on investment would not be reached. In the case of a $10 \%$ increase in hay price, the SI treatment would still be competitive in comparison to other treatments. Thus, the TSE will be cost effective only if the $\mathrm{N}$ price is taken into consideration. 


\section{Conclusions}

This study investigated the effects of irrigation using TSE combined with $\mathrm{N}$ fertilization on the productivity and quality of bermudagrass, and on its economic feasibility. Besides producing an economy of $33 \%$ in $\mathrm{N}$ fertilizer, irrigation with TSE increases $\mathrm{N}$ accumulation in the soil, DM production and leaf $\mathrm{N}$ concentration. The main influence of irrigation with TSE occurs in drought seasons with the increase in $\mathrm{N}$ concentration in bermudagrass shoots. The increase in leaf $\mathrm{N}$ concentration elevates the quality and the sales price for the harvested grass, thus optimizing the benefit-cost ratio for the producer.

\section{Acknowledgements}

The authors are grateful to FAPESP (São Paulo Research Foundation), for the support awarded to S.F. Nogueira and for financing the project (FAPESP process\# 04/14315-4). They also thank the support rendered by SABESP (Compania de Saneamento do Estado de São Paulo) staff.

\section{References}

Adeli, A., Varco, J.J., Rowe, D.E., 2003. Swine effluent irrigation rate and timing effects on bermudagrass growth, nitrogen and phosphorus utilization, and residual soil nitrogen. Journal of Environmental Quality 32 (2), 681-686.

Alvim, M.J., Xavier, D.F., Verneque, R.S., Botrel, M.A., 1999. Resposta do tifton 85 a doses de nitrogênio e intervalos de cortes. Pesquisa Agropecuária Brasileira 34 (12), 2345-2352.

Ayres, R.S., Westcot, D.S., 1985. Water Quality for Agriculture. FAO, Rome (Irrigation and Drainage Paper, 29).

Barton, L., Wan, G.G.Y., Colmer, T.D., 2006. Turfgrass (Cynodon dactylon L.) sod production on sandy soils: I. Effects of irrigation and fertiliser regimes on growth and quality. Plant and Soil 284 (1), 129-145.

Bergareche, C., Simon, E., 1989. Nitrate and ammonium accumulation in Bermudagrass in relation to nitrogen fertilization and season. Plant and Soil 119 (1), 51-57.

Bloom, A.J., 1997. Nitrogen as a limiting factor: crop acquisition of ammonium and nitrate. In: Jackson, L.E. (Ed.), Ecology in Agriculture. Academic, San Diego.

Eaton, A.D., Clesceri, L.S., Greenberg, A.E., 1995. Standard Methods for the Examination of Water and Wastewater, 19th ed. American Public Health Association, USA.

Fonseca, A.F., 2005. Agronomical-environmental viability of treated sewage effluent disposal on a soil-pasture system (In Portuguese). Piracicaba, Doctoral thesis - Escola Superior de Agricultura Luiz de Queiroz. Universidade de São Paulo, Piracicaba, SP.

Fonseca, A., Melfi, A., Monteiro, F., Montes, C., Almeida, V., Herpin, U., 2007. Treated sewage effluent as a source of water and nitrogen for Tifton 85 bermudagrass. Agricultural Water Management 87 (3), 328-336.

Frizzone, J.A., Silveira, S.F.R., 2000. Análise econômica de projetos hidroagrícolas. In: Silva, D.D.da., Pruski, F.F. (Eds.), Gestão de recursos hídricos: aspectoslegais, econômicos, administrativos e sociais. Ministério do Meio Ambiente, Secretaria de Recursos Hídricos/Universidade Federal de Viçosa, Associação Brasileira de Recursos Hídricos, Brasília/Viçosa.
Gloaguen, T.V., Forti, M.C., Lucas, Y., Montes, C.R., Gonçalves, R.A.B., Herpin, U., Melfi, A.J., 2007. Soil solution chemistry of a Brazilian Oxisol irrigated with treated sewage effluent. Agricultura Water Management 88, 119-131.

Hill, G.M., Gates, R.N., Burton, G.W., 1993. Forage quality and grazing steer performance from Tifton 85 and Tifton 78 bermudagrasses pastures. Journal of Animal Science 71 (12), 3219-3225.

Itavo, L.C.V., Filho, S.deC.V., Silva, F.F.da., Valadares, R.F.D., Cecon, P.R., Itavo, C.C.B.F., Moraes, E.H.B.K.de., Paulino, P.V.R., 2002. Níveis de concentrado e proteína bruta na dieta de bovinos nelore nas fases de recria e terminação: consumo e digestibilidade. Revista Brasileira de Zootecnia 31 (2), 1033-1041.

Lapponi, J.C., 2007. Projetos de investimentos na empresa. Elsevier, Rio de Janeiro.

Lemaire, G., Gastal, F.N., 1997. N uptake and distribution in plant canopies. In: Lemaire, G. (Ed.), Diagnosis of the Nitrogen Status in Crops. Springer, Berlin.

Lima, C.P., Backes, C., Villas Bôas, R., Oliveira, L., M.R. de Kiihl, T.A.M., Freitag, E.E., 2010. Bermuda grass sod production as related to nitrogen rates. Revista Brasileira De Ciência do Solo 34 (2), 371-378.

Lima, R.A.S., Shirota, R., Barros, G.S.C., 2006. Complex Study of Horse's Agrobusiness: Final Report. Cepea/Esalq/Universidade de São Paulo, Piracicaba - SP (In Portuguese).

Maas, E.V., 1985. Crop tolerance to saline sprinkling water. Plant and Soil 89 (1-3), 273-284.

Mancino, C.F., Pepper, I.L., 1992. Irrigation of turfgrass with secondary sewage effluent: soil quality. Agronomy Journal 84 (4), 650-654.

Meli, S., Porto, M., Belligno, A., Bufo, S.A., Mazzatura, A., Scopa, A., 2002. Influence of irrigation with lagooned urban wastewater on chemical and microbiological soil parameters in a citrus orchard under Mediterranean condition. The Science of the Total Environment 285 (1-3), 69-77.

Menzel, C.M., Broomhall, P., 2006. Response of tropical turfgrasses to recycled water in southern Queensland. Australian Journal of Experimental Agriculture 46 (12), 1645-1652.

Mishan, E.J., 1988. Cost-Benefit Analysis: An informal introduction, 4th ed. Unwin Hyman, London.

Oron, G., 1996. Soil as complementary treatment component for simultaneous wastewater disposal and reuse. Water Science and Technology 34 (11), 243-252.

Osborne, S.L., Raun, W.R., Johnson, G.V., Rogers, J.L., Wadell, A., 1999. Bermudagrass response to high nitrogen rates, source and season of application. Agronomy Journal 91 (3), 438-444.

Pereira, B.F.F., He, Z.L., Silva, M.S., Herpin, U., Nogueira, S.F., Montes, C.R., Melfi, A.J., 2011. Reclaimed wastewater: impact on soil plant system under tropical conditions. Journal of Hazardous Materials 192 (1), 54-61.

Soil Survey Staff, 1999. Soil taxonomy. In: Agriculture Handbook \#436, 2nd ed. USDA-NRCS, Washington, DC.

USDA, 2010. Fertilizers use and price; average U.S. farm prices of selected fertilizers. In: Economic Research Service. Agricultural Prices, National Agricultural Statistics Service, USDA, http://www.ers.usda.gov/Data/FertilizerUse/ (verified September 2010).

Vazquez-Montiel, O., Horan, N.J., Mara, D.D., 1996. Management of domestic wastewater for reuse in irrigation. Water Science and Technology 33 (10-11) 355-362.

Werner, J.C., Paulino, V.T., Cantarella, H., Andrade, N.O., Quaggio, J.A., 1996. Forrageiras. In: van raij, B., Cantarella, H., Quaggio, J.A., Furlani, A.M.C. (Eds.) Recommendation of Fertilizers and Liming for Sao Paulo State. , 2nd ed. Boletim Técnico \#100. Instituto Agronômico, Campinas, Brazil (In Portuguese).

Wherley, B.G., Shi, W., Bowman, D., Rufty, T., 2009. Fate of ${ }^{15} \mathrm{~N}$-nitrate applied to a bermudagrass system: assimilation profiles in different seasons. Crop Science 49 (6), 2291-2301.

Xiong, X., Bell, G.E., Solie, J.B., Smith, M.W., Martin, B., 2007. Bermudagrass seasonal responses to nitrogen fertilization and irrigation detected optical sensing. Crop Science 47 (4), 1603-1610. 